\title{
Toxicity of drilling fluids in aquatic organisms: a review
}

\author{
Aslan, J.F. ${ }^{1}$; Weber, L.I. ${ }^{2}$; IAnnacone, J. ${ }^{3}$; Lugon Junior,J. ${ }^{4}$ SARaiva, V.B. ${ }^{5}$ \& Oliveira, M.M. ${ }^{5}$ \\ ${ }^{1}$ PETROBRAS /Programa de Pós-Graduação em Engenharia Ambiental/IFFluminense - Macaé \\ ${ }^{2}$ Instituto de Biodiversidade e Sustentabilidade - Universidade Federal do Rio de Janeiro - Macaé \\ ${ }^{3}$ Universidad Nacional Federico Villarreal - Universidad Ricardo Palma - Peru \\ ${ }^{4}$ Programa de Pós-Graduação em Engenharia Ambiental - IFFluminense Campus Macaé \\ ${ }^{5}$ Laboratório de Ecotoxicologia e Microbiologia Ambiental - LEMAM - IFFluminense - Campus Cabo Frio
}

Received January 28, 2019; Accept July 10, 2019

\begin{abstract}
Offshore oil-well drilling has been a subject of great interest to environmental regulatory agencies worldwide. The drilling fluids used in this process involve a complex mixture of chemicals and are largely discharged into the ocean. Acute and chronic toxicity tests have been done to better understand the effects of different types of drilling fluids on aquatic organisms. The aim of this article was to analyze all the studies related to the toxicity of drilling fluids published during the period of 2000 to 2017 by conducting a thorough review through the Scopus and Science Direct databases. Out of 154 articles, only 25 showed relevant information about the toxicity of drilling fluids. Acute toxicity tests were the predominant tests employed, appearing in $56 \%$ of the articles. Invertebrates were the most evaluated taxa, used in $64 \%$ of cases and represented mainly by Crustacea (32\%), Mollusca (16\%), and other invertebrates. Vertebrates were represented only by fish, constituting $32 \%$ of the cases. Water-based drilling fluids (WBFs) $(32 \%)$ were the most frequently tested, followed by synthetic-based fluids or muds (SBFs) (24\%) and oil-based fluids (OBFs) (16\%). Individual components were tested in $12 \%$ of the cases, while 16\% of studies included more than one type of drilling fluid. After analyzing the toxicity of drilling fluids and the sensitivity of aquatic organisms presented in 25 articles published in scientific journals, we concluded that WBFs - showing, in general, lower values of median lethal concentrations than do natural oil- and SBFs - are the most toxic drilling fluids to invertebrates in the short term. The gaps of information found in this review indicate that future studies need to address the acute and chronic effects of WBFs in both juvenile and adult fish and in other vertebrates; they also need to address the chronic effects of nonaqueous-based fluids on adult invertebrates. As crustaceans are more sensitive to drilling fluids than are mollusks, it is also recommended that they be used in future studies.
\end{abstract}

Keywords: Ecotoxicology, drilling muds, drilling fluids, petroleum activities, acute and chronic toxicity.

\section{INTRODUCTION}

World oil production has increased over the last ten years from 3,954.2 million tonnes in 2007 to 4,387.1 million tonnes in 2017 (British Petroleum, 2018). The high level of oil and gas exploration activities at sea and the scarce data about the impact of their waste on aquatic ecosystems have challenged the established rules and guidelines for petroleum industrial managers.
Drilling is one of the main activities used for mineral exploration, including oil, which requires circulating fluids (i.e., drilling fluids or muds) in the borehole for formationcutting stabilization, lifting, and suspension, and for hole cleaning, bit cooling, surface pressure control, and drill string lubrication (Gandhi \& Sarkar, 2016). Different kinds of drilling fluids may be used, including water, bentonite mud, cutting oil, and polymers, which are categorized (according to their main component) as water-based fluids (WBFs), oil-

*Corresponding author: Manildo Marcião de Oliveira; e-mail: mmoliveira@iff.edu.br 
based fluids (OBFs) (Gandhi \& Sarkar, 2016), or syntheticbased fluids (SBFs) (Vincent-Akpuetal., 2010; ContrerasLeón et al., 2013).

Particles and other chemical components present in the formation cuttings may incorporate into the drilling fluid, and these become the main type of waste related to drilling fluid due to the large volumes that are generated and discharged. For this reason, the toxicity of drilling fluids is of concern to regulatory agencies, which require biological testing of the effect of the whole mix and of the individual components of drilling fluids (Sanzoneet al., 2018).

Laboratory toxicity tests provide useful empirical data to predict the biological effects of drilling fluids on aquatic environments. Tests are requested by environmental regulators for the granting of drilling license concessions at new fields. Scientific articles relating to this subject often present laboratory tests in which a range of pelagic and benthic species have been tested with some of the main drilling fluids currently in use by the petroleum industry.

Considering the large amounts and potential hazards of drilling-fluid waste within aquatic organisms, it is necessary to concentrate efforts on missing data and the data required for the development for management programs. Therefore, a review of the related literature is the first step in identifying and synthesizing the available relevant information about drilling fluids; thereafter, information gaps can be identified (Galvão \& Pereira, 2014; Gomes \& Caminha, 2014).

Therefore, the purpose of this review is to explore the main scientific studies on the toxicity of drilling fluids published during the period of 2000 to 2017 to obtain a global view of the existing knowledge, to identify the problems that remain unresolved, and to discern the prospects for progressing this area of study.

\section{MATERIALS AND METHODS}

The literature published in scientific periodicals within the period of January 2000 and October 2017 was obtained through a search of scientific articles in two important databases: Scopus and Science Direct. Three keywords were used in each search: "drilling fluids," "drilling muds," and "toxicity." The following data were compiled and analyzed using graphical representations within the Microsoft Excel program: number and type of articles per database; type of drilling fluids or components tested; species used to evaluate toxicity and their taxonomic levels; type of test, in accordance with the time of exposure and level of damage analyzed; the journal, and its impact factor, in which the article was published; the country where the study took place; and the levels of contaminants that promoted a response in the tested organisms. In order to understand and draw conclusions about gaps of information and the levels of toxicity of the different types of drilling fluids, we summarize their effects by taxonomical level (vertebrates and invertebrates), by ontogenetic stage (gametes, postlarvae, juveniles, and adults), by short- and long-term effect (acute and chronic tests), and by type of drilling fluids or muds (water-based fluids [WBFs] or non-aqueous-based fluids $[\mathrm{NABF}]$, which includes natural oil-based fluids [OBFs] and synthetic-based fluids [SBFs]).

\section{RESULTS AND DISCUSSION}

\section{Articles' contributions by database, journal, and country}

A total of 154 articles were obtained by searching both databases. Of those, 151 articles were found in Scopus and 24 articles were found in Science Direct. Twenty-one articles were found in both databases (Figure 1). Most articles evaluated the operational performance of drilling fluids and their products, with little or no relevant toxicological information. Only 25 articles included related to the toxicity of drilling fluids to aquatic organisms, and therefore, these articles were chosen for further analysis (Table 1).

Studies related to drilling fluids' toxicity, a relevant and current topic, have been published in scientific journals with high impact factors, such as the Marine Pollution Bulletin, Environmental Pollution, and Marine Environmental Research. Forty-four percent of the identified articles were published in journals with an impact factor higher than 2.0 (see Table 1). The countries that have emerged as new exploratory frontiers for petroleum, such as Nigeria and Australia, contributed the greatest number of studies on the toxicity of drilling fluids during the period of January 2000 to October 2017 (Fig. 2).

\section{Most represented tests, in accordance with time of exposure}

The time of exposure and the criteria used for evaluating toxicity determine which kind of test is applied: acute or chronic. Acute tests correspond with short-exposure tests (usually lasting 1 to 4 days) and use the mortality or loss of activity of the test organisms as evaluation criteria. Chronic tests, in contrast, evaluate sublethal levels of

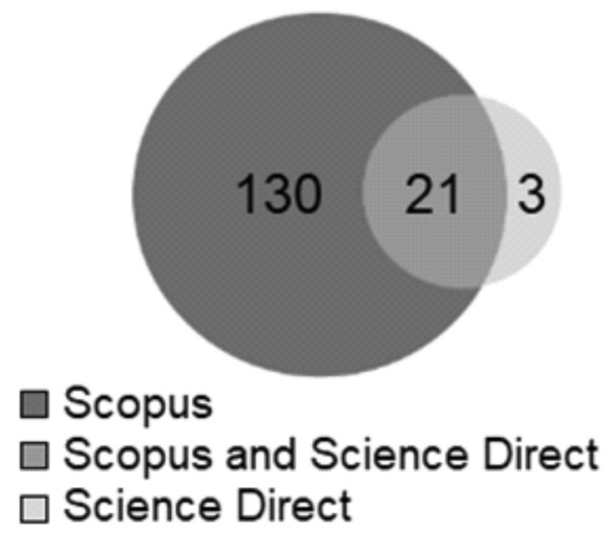

Figure 1. Articles published during the period of January 2000 to October 2017, found in the Scopus and Science Direct databases, which showed relevant information about the toxicity of drilling fluids 
Table 1. Articles with relevant toxicological information about drilling fluids published during the period of January 2000 to October 2017, obtained from the Scopus and Science Direct databases, indicating the impact factor of their respective journals, in accordance with Journal Citation Reports of 2016 (https://www.ufrb.edu.br/pgcienciasagrarias/images/Edital_primeiro_semestre_2018/2017JournalImpactFactor.pdf).

\begin{tabular}{|c|c|c|c|c|c|c|}
\hline Drilling fluid & Species & $\begin{array}{c}\text { Taxonomic } \\
\text { level }\end{array}$ & Test type & Journal & $\begin{array}{l}\text { Impact } \\
\text { factor }\end{array}$ & Authors, year \\
\hline WBFs & Calanus finmarchicus & $\begin{array}{l}\text { Crustacea, } \\
\text { Copepoda }\end{array}$ & Acute & $\begin{array}{l}\text { J. Toxicol. } \\
\text { Environ. } \\
\text { Health, A }\end{array}$ & $\begin{array}{l}2.731 \\
(2016)\end{array}$ & Farkas et al., 2017 \\
\hline ACs & Vibrio fischeri & Proteobacteria & Acute & $\begin{array}{l}\text { Drilling Fluid } \\
\text { Completion } \\
\text { Fluid }\end{array}$ & $\begin{array}{c}0.350 \\
(2015)\end{array}$ & Zhu and Liu, 2015 \\
\hline WBFs & $\begin{array}{l}\text { Lytechinus variegatus } \\
\text { (sea urchin) }\end{array}$ & Equinodermata & Acute & $\begin{array}{l}\text { Bol. Invest. } \\
\text { Mar. Cost. }\end{array}$ & $\begin{array}{c}0.100 \\
(2016)\end{array}$ & $\begin{array}{l}\text { Benavides et al., } \\
2014\end{array}$ \\
\hline $\begin{array}{l}\text { SBFs (EBF, } \\
\text { IOBF, LAOBF) }\end{array}$ & $\begin{array}{l}\text { Pagrus auratus } \\
\text { (Fish) }\end{array}$ & $\begin{array}{l}\text { Actinopterygii, } \\
\text { Perciformes }\end{array}$ & $\begin{array}{l}\text { Acute and } \\
\text { Chronic }\end{array}$ & PLOS ONE & $\begin{array}{l}2.806 \\
(2016)\end{array}$ & $\begin{array}{c}\text { Gagnon and } \\
\text { Bakhtyar, } 2013\end{array}$ \\
\hline WBFs and SBFs & $\begin{array}{c}\text { Litopenaeus vannamei } \\
\text { (Shrimp) }\end{array}$ & $\begin{array}{l}\text { Crustacea, } \\
\text { Decapoda }\end{array}$ & Acute & $\begin{array}{c}\text { Ciencia, Tecnol. } \\
\text { Futuro }\end{array}$ & $\begin{array}{c}0.310 \\
(2016)\end{array}$ & $\begin{array}{c}\text { Contreras-León et } \\
\text { al., } 2013\end{array}$ \\
\hline SBF (Parateq) & $\begin{array}{c}\text { Oreochromis niloticus } \\
\text { (Nile Tilapia) }\end{array}$ & $\begin{array}{l}\text { Actinopterygii, } \\
\text { Cichliformes }\end{array}$ & Acute & $\begin{array}{l}\text { Jour. Fish. } \\
\text { Aquat. Science }\end{array}$ & $\begin{array}{c}0.630 \\
(2016)\end{array}$ & $\begin{array}{l}\text { Vincent-Akpu and } \\
\text { Sikoki, } 2013\end{array}$ \\
\hline $\begin{array}{l}\text { Water-based } \\
\text { individual } \\
\text { components } \\
\text { (standard barite, } \\
\text { fine barite, } \\
\text { ilmenite, and } \\
\text { bentonite) }\end{array}$ & $\begin{array}{c}\text { Modiolus modiolus } \\
\text { Venerupis senegalensis } \\
\text { Dosinia exoleta } \\
\text { Chlamys varia }\end{array}$ & $\begin{array}{l}\text { Mollusca, } \\
\text { Bivalvia }\end{array}$ & Chronic & $\begin{array}{c}\text { Mar. Pollut. } \\
\text { Bull. }\end{array}$ & $\begin{array}{l}3.146 \\
(2016)\end{array}$ & $\begin{array}{c}\text { Strachan and } \\
\text { Kingston, } 2012\end{array}$ \\
\hline $\begin{array}{l}\text { OBFs (Rheosyn } \\
\text { 1416) }\end{array}$ & $\begin{array}{l}\text { Pagrus auratus } \\
\text { (Fish) }\end{array}$ & $\begin{array}{l}\text { Actinopterygii, } \\
\text { Perciformes }\end{array}$ & Chronic & $\begin{array}{c}\text { Environ. Monit. } \\
\text { Assess. }\end{array}$ & $\begin{array}{l}1.687 \\
(2016)\end{array}$ & $\begin{array}{l}\text { Bakhtyar and } \\
\text { Gagnon, } 2012\end{array}$ \\
\hline OBFs & $\begin{array}{c}\text { Tilapia mossambica } \\
\text { Boleopthalmus boaddarti } \\
\text { Mugil persia }\end{array}$ & $\begin{array}{l}\text { Actinopterygii, } \\
\text { Perciformes }\end{array}$ & Acute & $\begin{array}{c}\text { J. Hazard. } \\
\text { Toxic Radioact. } \\
\text { Waste }\end{array}$ & $\begin{array}{c}0.740 \\
(2015)\end{array}$ & Sil et al., 2012 \\
\hline $\begin{array}{l}\text { Metals at levels } \\
\text { observed in } \\
\text { drilling muds } \\
\text { (barium and } \\
\text { cadmium) }\end{array}$ & $\begin{array}{c}\text { Rhabditis (Pellioditis) } \\
\text { marina }\end{array}$ & Mugiliformes & $\begin{array}{l}\text { Acute and } \\
\text { Chronic }\end{array}$ & $\begin{array}{l}\text { Mar. Environ. } \\
\text { Res. }\end{array}$ & $\begin{array}{l}3.101 \\
(2016)\end{array}$ & Lira et al., 2011 \\
\hline OBFs & $\begin{array}{c}\text { Palaemonetes africanus } \\
\text { (Shrimp) }\end{array}$ & $\begin{array}{l}\text { Crustacea, } \\
\text { Decapoda }\end{array}$ & Acute & $\begin{array}{c}\text { Afr. J. Aquat. } \\
\text { Sci. }\end{array}$ & $\begin{array}{c}0.670 \\
(2016)\end{array}$ & $\begin{array}{l}\text { Ogeleka and } \\
\text { Tudararo- } \\
\text { Aherobo, } 2011\end{array}$ \\
\hline
\end{tabular}


Table 1. Articles with relevant toxicological information about drilling fluids published during the period of January 2000 to October 2017, obtained from the Scopus and Science Direct databases, indicating the impact factor of their respective journals, in accordance with Journal Citation Reports of 2016 (https://www.ufrb.edu.br/pgcienciasagrarias/images/Edital_primeiro_semestre_2018/2017JournalImpactFactor.pdf).

\begin{tabular}{|c|c|c|c|c|c|c|}
\hline Drilling fluid & Species & $\begin{array}{c}\text { Taxonomic } \\
\text { level }\end{array}$ & Test type & Journal & $\begin{array}{l}\text { Impact } \\
\text { factor }\end{array}$ & Authors, year \\
\hline SBF (XP-07) & Tilapia guineensis & $\begin{array}{l}\text { Actinopterygii, } \\
\text { Perciformes }\end{array}$ & Acute & Ciência Rural & $\begin{array}{l}0.417 \\
(2016)\end{array}$ & $\begin{array}{c}\text { Vincent-Akpuet } \\
\text { al., } 2010\end{array}$ \\
\hline ACs (lubricants) & $\begin{array}{c}\text { Palaemonetes africanus } \\
\text { (Shrimp) }\end{array}$ & $\begin{array}{l}\text { Crustacea, } \\
\text { Decapoda }\end{array}$ & Acute & $\begin{array}{c}\text { Toxicol. } \\
\text { Environ. Chem. }\end{array}$ & $\begin{array}{l}0.795 \\
(2016)\end{array}$ & Otaigbeet al., 2006 \\
\hline $\mathrm{ACs}$ & Neomysisa watschensis & $\begin{array}{l}\text { Crustacea, } \\
\text { Mysida }\end{array}$ & Acute & J. Environ. Sci. & $\begin{array}{l}2.937 \\
(2016)\end{array}$ & Yan et al., 2003 \\
\hline
\end{tabular}

Review of all types of drilling fluids

SBFs (EBF,
IOBF, and
paraffin)

OBF (diesel oil) and SBF (IOBF)

OBFs and WBFs
Leptocheirus plumulosus

Crustacea, Amphipoda
Acute and
Chronic

Crustacea,

Amphipoda

Mollusca, Bivalvia

Acute

Paphies elongata

Actinopterygii, Perciformes

Acute

Acute

$$
\begin{aligned}
& \text { Environ. } \\
& \text { Toxicol. }
\end{aligned}
$$

2.937

(2016)

2.937

(2016)

Tsvetnenkoet al.,

Jordan J. Biol. Sci.

Not found

Imarhiagbe and Atuanya, 2017 OBFs (washed
and non-washed
fluids)

WBFs (barite and bentonite)

WBFs and SBFs Argopecten nucleus (Shrimp)

Geodia barretti
Desmoscaris trispinosa, Palaemonetes africanus
5.099

(2016)

0.955

(2016)

0.100

(2016) 2000

Holdway, 2002

Still et al., 2000

Porifera
(sponges)

Acute and Chronic

Environ. Pollut.

Mollusca, Bivalvia

Acute and

\begin{tabular}{|c|c|c|c|c|}
\hline $\begin{array}{l}\text { Crustacea, } \\
\text { Decapoda }\end{array}$ & Acute & Arab. J. Geosci. & $\begin{array}{c}0.955 \\
(2016)\end{array}$ & $\begin{array}{c}\text { Okogbueet al., } \\
2016\end{array}$ \\
\hline
\end{tabular}
Chronic

Bol. Invest. Mar. Cost.
RodríguezSatizábalet al., 2015
Denoyelleet al., 2012 
Table 1. Articles with relevant toxicological information about drilling fluids published during the period of January 2000 to October 2017 , obtained from the Scopus and Science Direct databases, indicating the impact factor of their respective journals, in accordance with Journal Citation Reports of 2016 (https://www.ufrb.edu.br/pgcienciasagrarias/images/Edital_primeiro_semestre_2018/2017JournalImpactFactor.pdf).

\begin{tabular}{|c|c|c|c|c|c|c|}
\hline Drilling fluid & Species & $\begin{array}{c}\text { Taxonomic } \\
\text { level }\end{array}$ & Test type & Journal & $\begin{array}{l}\text { Impact } \\
\text { factor }\end{array}$ & Authors, year \\
\hline SBFs & $\begin{array}{c}\text { Oreochromis } \\
\text { mossambicus } \\
\text { (Tilapia) }\end{array}$ & $\begin{array}{c}\text { Actinopterygii, } \\
\text { Perciformes }\end{array}$ & $\begin{array}{l}\text { Acute and } \\
\text { Chronic }\end{array}$ & $\begin{array}{c}\text { Polycyclic } \\
\text { Aromatic } \\
\text { Compounds }\end{array}$ & $\begin{array}{l}1.568 \\
(2016)\end{array}$ & $\begin{array}{c}\text { Jagwaniet al., } \\
2011\end{array}$ \\
\hline
\end{tabular}

\begin{tabular}{|c|c|c|c|c|c|c|}
\hline $\begin{array}{l}\text { WBFs (barite and } \\
\text { bentonite) }\end{array}$ & $\begin{array}{c}\text { Cerastoderma edule } \\
\text { Macoma balthica }\end{array}$ & $\begin{array}{l}\text { Mollusca, } \\
\text { Bivalvia }\end{array}$ & $\begin{array}{l}\text { Acute and } \\
\text { Chronic }\end{array}$ & $\begin{array}{c}\text { Mar. Pollut. } \\
\text { Bull. }\end{array}$ & $\begin{array}{l}3.146 \\
(2016)\end{array}$ & $\begin{array}{l}\text { Barlow and } \\
\text { Kingston, } 2001\end{array}$ \\
\hline SBF (Parateq) & Tilapia guineensis & $\begin{array}{l}\text { Actinopterygii, } \\
\text { Perciformes }\end{array}$ & $\begin{array}{l}\text { Acute and } \\
\text { Chronic }\end{array}$ & $\begin{array}{l}\text { Rev. Cientifica } \\
\text { UDO Agrícola }\end{array}$ & $0.18(2014)$ & $\begin{array}{c}\text { Vincent-Akpu and } \\
\text { Chindah, } 2009\end{array}$ \\
\hline
\end{tabular}

AC: additive component; EBF: ester-based fluid; IOBF: isomerized olefin-based fluid; LAOBF: linear alfa olefin-based fluid; OBF: oil-based fluid; SBF: synthetic-based fluid; WBF: water-based fluid.

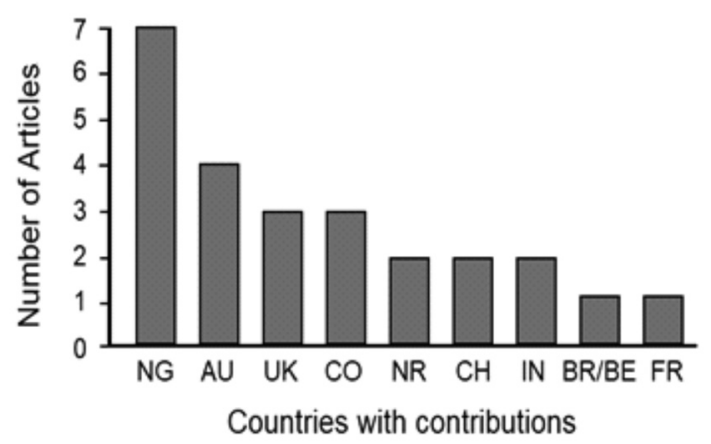

Figure 2. Number of articles published per country during the period of January 2000 to October 2017. NG: Nigeria; AU: Australia; UK: United Kingdom; CO: Colombia; NR: Norway; CH: China; IN: India; BR/BE: Brazil/Belgium; FR: France.

toxicity during long-term exposure (usually lasting more than 10 days)

Most articles that evaluated the toxicity of drilling fluids applied acute tests (56\%), while only three performed longlasting exposure assays (i.e., chronic tests; Fig. 3). The low cost and simple execution of acute tests make them the preferred and most used tests (Zagatto and Bertoletti, 2008). However, as a result, the lack of long-term exposure studies to evaluate sublethal levels of toxicity in aquatic organisms has been recognized (Denoyelleet al., 2012); this means there is currently little background information available about the chronic effects of toxic components in drilling fluids, and it is these that have a larger probability of having effects at the population level.

\section{Test organisms}

A number of parameters must be considered when selecting a species in which to evaluate toxicity, and it is not always possible select a species that is ideal in relation to each of these parameters. Ideally, a group of species representing

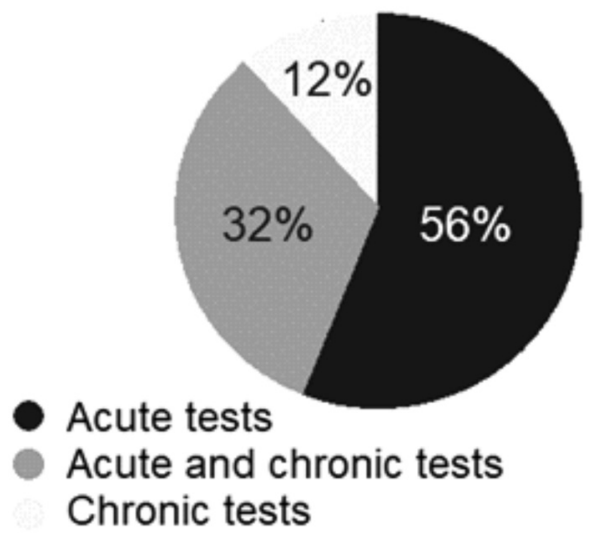

Figure 3. Percentage shares of the different types of tests, applied in accordance with the time of exposure, in studies published during the period of January 2000 to October 2017.

a wide range of sensitivities should be used (Rand, 1995), but this is rarely possible due to the high cost of a multi-species approach. Rand (1995) recommended the following criteria be used when choosing an animal for testing: it should be of high abundance and availability; be a component of the ecosystem that is suffering the impact of toxins; be commercially or ecologically important; and be easy to manage through routine laboratory maintenance.

It was found in this review that the most used taxa for studying drilling fluids were invertebrates (64\%), while vertebrates, represented exclusively by fish, were used in only $32 \%$ of the studies (Fig. 4). Fish are located at the top of the food chain and are highly visible resources. Fish, as aquatic organisms, are heavily affected by pollutants due to their direct contact with water through their body surface and gills. Because fish are food resources for humans, this becomes a food safety issue; fish and fishery products are generally considered to be at a high risk for pathogens, natural toxins, and other possible contaminants. 
Invertebrates were mostly represented by crustaceans, which were used at the same rate as were fish (Fig. 4). Among crustaceans, shrimp were the most tested organisms, followed by amphipods and copepods. Palaemonetes africanus, a shrimp species of brackish water and prey of large vertebrates, was used by Ogeleka and Tudararo-aherobo (2011) to study the acute toxicity of a non-aqueous-based drilling fluid. This organism, which is easily transported and maintained in laboratory conditions, produced consistent and reproducible responses to toxic substances. The bivalve Argopecten nucleus was used by Rodríguez-Satizábalet al. (2015) as test organisms for evaluating the acute and chronic effects of drilling fluids in Colombia. This species is widely distributed in the Caribbean; it is a commercially important species in Colombia, and the technology for culturing and reproduction in laboratories has already been established. The shrimp species Litopenaeus vannamei was also used in Colombia for short-term toxicity tests of drilling fluids (WBFs and SBFs) (Contreras-León et al., 2013). The species is distributed from southern Mexico to northern Peru and represents an important portion of the industrial and artisanal fishery industry of the Colombian Pacific coast. This species has also been successfully introduced in commercial farming facilities. Denoyelleet al. (2012) used the benthic foraminifera Ammonia tepida for the chronic evaluation of drilling fluid toxicity due to their long-term exposure sensitivity to pollutants, detected by physiological responses such as pseudopodal activity and chamber addition. Since the 1960s, foraminifera have increasingly been used as bioindicators of anthropogenic impacts on marine environments. They are unicellular organisms protected externally by a calcareous shell, and they are found in all marine latitudes. They show different forms at different trophic levels (e.g., planktonic or benthonic) and therefore have different levels of sensitivity to chemical compounds (Denoyele et al., 2012). Other groups of crustaceans that have been used for evaluating the toxicity of drilling fluids are amphipods and copepods. Amphipods are sensitive organisms that are easy to maintain, have low maintenance costs, and have good reproducibility, allowing for the selection of low-toxicity drilling fluids. Examples of amphipods are Grandidierella sp. and Leptocheirus plumulosus, which have beenused to compare the toxicity of SBFs (Tsvetnenkoet al., 2000; Still et al., 2000).

\section{Types of drilling fluids}

The exact chemical composition of the all varieties of drilling fluids are not known, but studies on their general composition have revealed that they contain complex mixtures of highly volatile materials and toxic substances, such as aromatic compounds and heavy metals (Vincent-Akpu et al., 2010). Drilling fluids are classified as either WBFs (or muds WBMs) or as non-aqueous-based fluids ([NABFs] or muds [NABMs]), in accordance with the chemical composition of the base of the fluid (Ogeleka \&Tudararo-Aherobo, 2011). WBFs include barite, bentonite, lignite, and lignosulphonate, with a limited list of additive products (Holdway, 2002). NABFs are divided further into OBFs, enhanced mineral oil-based fluids (EMOBFs), and SBFs (Ogeleka \&TudararoAherobo, 2011). Within SBFs are ester-based fluids (EBFs), isomerized olefin-based fluids (IOBFs), and linear alfa olefinbased fluids (LAOBFs) (Ogeleka \&Tudararo-Aherobo, 2011; Gagnon \& Bakhtyar, 2013). WBFs were the most frequently tested muds in the present review, appearing in 25 of the studied articles (Fig. 5). OBFs were the least tested during the period of January 2007 to October 2017.

\section{Effect of different types of drilling fluids on aquatic organisms}

Holdway (2002) reviewed articles that examined the chronic and acute effects of drilling fluids and chemical additives in temperate and tropical marine environments, and, at that time, drew attention to the need for long-lasting studies and to perform experiments with fluid dispersion as it occurs in real environments, in order to understand exposure concentrations and the effects of dilution at sea. The author also concluded that drilling fluids with larger amounts of anti-foams and wetting agents (both mixtures of surfactants) would have significantly greater toxicities. The effects of
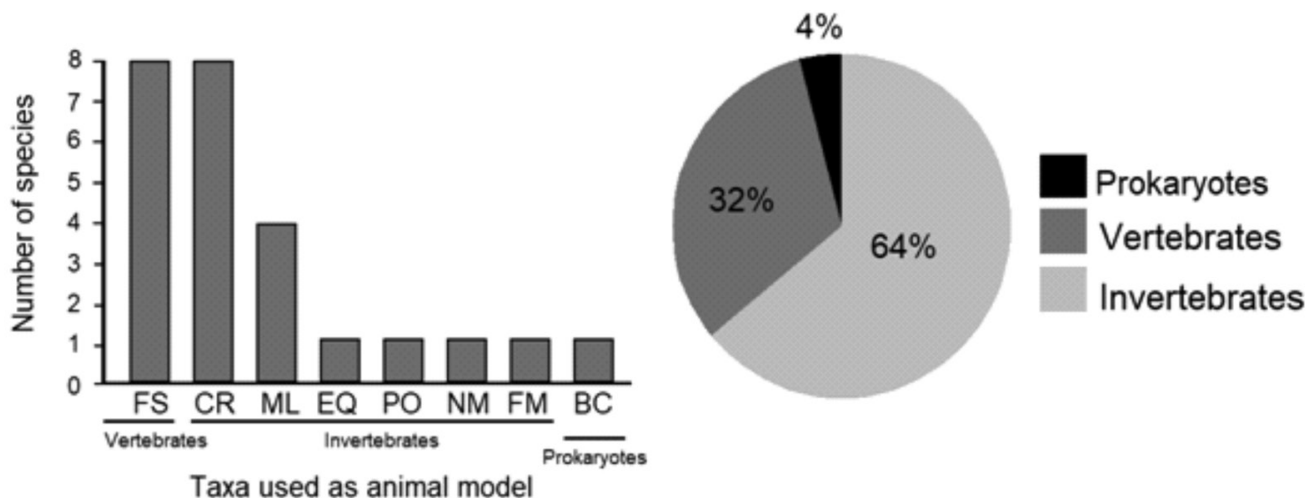

Figure 4. Number and percentage of species by taxonomic classification used as animal models for evaluating the toxicity of drilling fluids, the results of which were published during the period of January 2000 to October 2017. FS Fish; CR: Crustacea; ML: Mollusca; EQ: Equinodermata; PO: Porifera; NM: Nematoda; FM: Foraminifera; BC: Bacteria. 
different drilling fluids and their components observed within this review, in relation to be short- and long-term exposure, are listed in Table 2.

\section{Effects on vertebrates}

\section{Acute effects}

There was no available information about the acute effects of SBFs on juvenile fish or of WBFs on adult fish (Table 3). The median lethal component $\left(\mathrm{LC}_{50}\right)(96 \mathrm{~h})$ for juvenile fish ranged from $125 \mathrm{mg} \mathrm{L}^{1}$ for WBFs to $6,000 \mathrm{mg} \mathrm{L}^{-1}$ for natural OBFs (Imarhiagbe and Atuanya, 2017), indicating the higher toxicity of WBF than of OBF for juvenile fish (Table 3).

In adult fish, toxicity varied depending on which drilling mud phase was tested and to which kind of habitat the fish was adapted. The $\mathrm{LC}_{50}(96 \mathrm{~h})$ for $\mathrm{OBF}$ in adult fish varied from $16,713 \mathrm{mg} \mathrm{L}^{-1}$ for OBFs in marine fish to $770,000 \mathrm{mg}$ $\mathrm{L}^{-1}$ of the suspended particulate phase (SPP) in freshwater fish (Table 3). For SBF, the $\mathrm{LC}_{50}(96 \mathrm{~h})$ varied from 2,210 $\mathrm{mg} \mathrm{L}^{-1}$ (Parateq) to $40,390 \mathrm{mg} \mathrm{L}^{-1}$ of the SPP of an Indian well. In accordance with the data presented by Sil et al.(2012), marine fish are more sensitive to drilling fluids than are freshwater or benthonic fish (see Table 3), and Parateq appears to be the most toxic of the tested fluids to vertebrates, as measured in adult fish. Comparing juveniles and adults, WBF was most toxic to juveniles $\left(125 \mathrm{mg} \mathrm{L}^{-1}\right)$, followed by OBF to juveniles $\left(6,000 \mathrm{mg} \mathrm{L}^{-1}\right)$ and $\mathrm{OBF}$ to adult marine fish $\left(16,713 \mathrm{mg} \mathrm{L}^{-1}\right)$.

\section{Chronic effects}

Short-term bioassays assessing mortality as the main response substantially underestimate the effects of toxicants at the population level (Lira et al., 2011). Physiological and behavioral changes observed in chronic toxicity tests enable the evaluation of subtle adverse effects on the exposed organisms. Chronic effects will, in turn, result in changes in population parameters, such as a decreased survival because of disfunction or carcinogenicity, due to the cumulative effect of the toxicant; decreased survival in the early life stages of

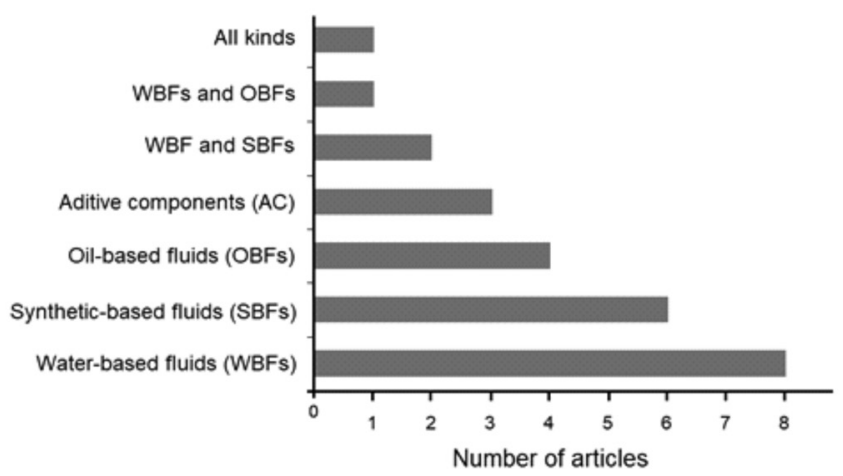

Figure 5. Types of drilling fluids tested in the 25 articles included in this review. the following generations due to abnormalities in early life stages; and decreased fertility and fecundity due to abnormal gametes. Although chronic assays have a higher cost and are more time-consuming, they provide more accurate information about the toxicity of substances (Zagatto and Bertoletti, 2008). Despite their importance, the chronic effects of drilling fluids on vertebrates (fish, in this case) have been neglected in both juveniles and adults, as this has been evaluated only for SBFs. Therefore, no data is available to indicate the toxic effects of WBF and OBF on fish.

Gagnon and Bakhtyar (2013) investigated the chronic effects of SBF and its components in juvenile pink snappers (Pagrus auratus) after long-term exposure. The authors evaluated ethoxyresorufin-O-deethylase (EROD) activity, biliary metabolites, DNA damage, stress proteins, and other physiological conditions, which allowed them to conclude that although SBF may be non-toxic in the short term, it does have an effect on the health of juvenile fish in the long term. They found that after 20 days of exposure to SBF, the EROD, sorbitol dehydrogenase (SDH), and heat shock protein (HSP)-70 activities increased, as did the pyrene metabolite and DNA damage. In adult fish, after three months' exposure to SBF, a decrease in oocyte maturation and delayed spermatogenesis, preventing fertilization, were observed (Table 3). Bakhtyar and Gagnon (2012) found that some additive components (ACs) were less toxic than others, suggesting that replacing some ACs with less toxic components, as evaluated by chronic tests, may reduce the impact of drilling fluids on the aquatic biota.

\section{Effects on invertebrates}

Invertebrates have largely been used to evaluate the toxicity of WBF on aquatic organisms in both the short and long term. However, the long-term effects have not been studied as closely, with the long-term effect of SBF and OBF having only been evaluated in foraminifera.

\section{Acute effects}

Although there is a long list of studies on the short-term effects of toxins on invertebrates, there is no information available about the toxicity of OBF to juvenile invertebrates. WBF prevents the fertilization of Echinodermata gametes after $1 \mathrm{~h}$ of exposure to 3,649 $\pm 400 \mathrm{mg} \mathrm{L}^{-1}$ (Benavides et al., 2014). The $\mathrm{LC}_{50}(96 \mathrm{~h})$ in post-larvae crustaceans varied from 4,224 ppm of WBF to 308,248 ppm of SBF (Contreras-León et al., 2013), indicating the higher toxicity of WBF (Table 4). Juveniles mollusks were less sensitive than were crustaceans, with an $\mathrm{LC}_{50}(96 \mathrm{~h})$ that varied from 9,113 ppm of $\mathrm{WBF}$ to $>1,000,000 \mathrm{ppm}$ of SBF (Rodríguez-Satizábalet al., 2015), while juveniles crustaceans may be sensitive to 12,000 pp of SBF (Yan et al., 2003) (Table 4).

The $\mathrm{LC}_{50}(96 \mathrm{~h})$ in adult crustaceans may varied from 320 mg L ${ }^{-1}$ of WBF (Farkas et al., 2017) to $17,200 \mathrm{mg} \mathrm{L}^{-1}$ of OBF (Okogbueet al., 2016), showing, again, the higher toxicity of WBF than of OBF. The toxic effect of synthetic fluids may 
Table 2. Data from the reviewed articles showing the effects after short- and long-term exposure to different drilling muds.

\begin{tabular}{lcccccc}
\hline Drilling fluid & Species & Test type & $\begin{array}{c}\text { Time of } \\
\text { exposure }\end{array}$ & Animal stage & $\begin{array}{c}\text { Authors, } \\
\text { year }\end{array}$ \\
\hline WBFs & $\begin{array}{c}\text { Calanus finmarchicus } \\
\text { (Crustacea) }\end{array}$ & Acute & $96 \mathrm{~h}$ & $\begin{array}{c}\text { Adults } \\
\text { (stage V) }\end{array}$ & LC50 = $320 \mathrm{mg} \mathrm{L}^{-1}$ & $\begin{array}{c}\text { Farkas et al., } \\
2017\end{array}$
\end{tabular}

WBFs

Lytechinus variegatus

(Echinodermata)

SBFs (EBF, IOBF, and $\mathrm{LAOBF}$ )

(Fish)

Chronic

$28 \mathrm{~d}$

Juveniles

WBFs and SBFs

Litopenaeus vannamei

(Crustacea)

Acute

$96 \mathrm{~h}$

Post-larvae

Oreochromis niloticus (Fish)

Acute

$96 \mathrm{~h}$

Adults

Modiolus modiolus (Mm)

individual

components

(standard barite,

fine barite,

ilmenite, and

bentonite)

Synthetic OBFs

(Rheosyn 1416)

and individual

components

OBFs

$(\mathrm{Vs})$
Dosinia exoleta $(\mathrm{De})$
Chlamys varia $(\mathrm{Cv})$
(Mollusca)

Tilapia mossambica $(\mathrm{Tm})$ Boleopthalmusboddarti

$$
\begin{gathered}
\text { Mugil persia (Mp) } \\
\text { (Fish) }
\end{gathered}
$$

Metals at levels observed in

drilling muds

(barium and

cadmium)

OBF

(GlycolTM)

\section{Rhabditis (Pellioditis)}

marina

(Nematoda)

Palaemonetes africanus

(Crustacea)
Chronic $28 \mathrm{~d} \quad$ Adults

Chronic

Juveniles

$$
\text { Acute }
$$

$96 \mathrm{~h}$

Adults

Chronic

10 days ( 2 generations)

Adult males and gravid females

Acute
Fecundity inhibition,

$\mathrm{EC} 50=3,649 \pm 400 \mathrm{mg} \mathrm{L}^{-1}$

IOBF and LAOBF: increased EROD activity;

LAOBF: increased HSP-70; no DNA damage

WBF: LC50 = 4,224 -26,635 ppm

SBF: $\operatorname{LC} 50=40,781-308,248$ ppm

$\mathrm{LC} 50=2,210 \mathrm{mg} \mathrm{L}^{-1}$

Bentonite: increased filtration rate; bentonite and fine barite: no lethal

$$
\text { response; }
$$

ilmenite and standard barite: gill damage and lethal response at days 4-5 $(\mathrm{Cv})$, day $11(D e)$, days 9-12 (Vs), and day 19 $(\mathrm{Mm})$

Increased EROD activity with Emul S50, LSL 10, Bentone 38; increased pyrene metabolite with mud Syndrill 80:20, Emul S50, Wetout, and LSL 10; increased SDH activity with Syndrill 80:20, Emul S50; DNA damage with Syndrill 80:20, Emul S50, and LSL 10 SP: LC50 $=200,000 \mathrm{mg} \mathrm{L}^{-1}$ in freshwater fish $(\mathrm{Tm})$ and $31,107 \mathrm{mg} \mathrm{L}^{-1}$ in marine fish (Mp); SPP: 770,000 $\mathrm{mg} \mathrm{L}^{-1}(\mathrm{Tm})$ and 42,614 $\mathrm{mg} \mathrm{L}^{-1}(M p) ; 243,652 \mathrm{mg}$ $\mathrm{kg}^{-1}$ in benthic organisms $(B b)$; OBF: 22,414 $\mathrm{mg} \mathrm{L}^{-1}(T m), 16,713 \mathrm{mg} \mathrm{L}^{-1}(M p)$, and $167,340 \mathrm{mg} \mathrm{kg}^{1}(B b)$

Barium: 400-2,000 ppm decreased population abundance

and increased time of development; Lira et al., $\mathrm{LOEC}=2.95 \mathrm{ppm}, \mathrm{EC} 50=8.82 \mathrm{ppm}$; Cadmium: 2.40-2.68 ppm decreased population abundance

LC50 = $101 \mathrm{mg} \mathrm{kg}^{-1}$ (95\% CI: 49-153 $\left.\mathrm{mg} \mathrm{kg}^{-1}\right)$
Benavides et

al., 2014

Gagnon and

Bakhtyar, 2013

Contreras-

León et al., 2013

Vincent-

Akpu and

Sikoki, 2013

Strachan and

Kingston, 2012

Bakhtyar and Gagnon,

2012

Sil et al., 2012 2011

Ogeleka and TudararoAherobo, 2011 
Toxicity of drilling fluids in aquatic organisms:...

Table 2. Data from the reviewed articles showing the effects after short- and long-term exposure to different drilling muds.

\begin{tabular}{|c|c|c|c|c|c|c|}
\hline Drilling fluid & Species & Test type & $\begin{array}{l}\text { Time of } \\
\text { exposure }\end{array}$ & Animal stage & Response & $\begin{array}{l}\text { Authors, } \\
\text { year }\end{array}$ \\
\hline SBF (XP-07) & $\begin{array}{l}\text { Tilapia guineensis } \\
\text { (Fish) }\end{array}$ & Acute & $96 \mathrm{~h}$ & $\begin{array}{l}\text { Fry, } \\
\text { fingerling, } \\
\text { and post- } \\
\text { fingerling }\end{array}$ & $\begin{array}{rl}\text { LC50 } 5 & 5.63 \% \text { (fry), } 7.77 \% \text { (fingerling), } \\
& 6.93 \% \text { (post fingerling) }\end{array}$ & $\begin{array}{l}\text { Vincent- } \\
\text { Akpuet al., } \\
2010\end{array}$ \\
\hline ACs (lubricants) & $\begin{array}{c}\text { Palaemonetes africanus } \\
\text { (Crustacea) }\end{array}$ & Acute & $96 \mathrm{~h}$ & Adult & $\begin{array}{l}\text { Lubricant } 1 \text { : } \mathrm{LC} 50=350 \mathrm{mg} \mathrm{L}^{-1} \text {; } \\
\text { lubricant } 2 \text { of high molecular weight: } 210 \\
\mathrm{mg} \mathrm{L}{ }^{-1} \text {, less diffusion; lubricant } 3 \text { of high } \\
\text { acidity: } 620 \mathrm{mg} \mathrm{L}^{-1} \text {. }\end{array}$ & $\begin{array}{l}\text { Otaigbeet } \\
\text { al., } 2006\end{array}$ \\
\hline ACs & Neomysisa watschensis & Acute & $96 \mathrm{~h}$ & Juveniles & $\begin{array}{l}\text { SPP: } \mathrm{LC} 50=12,000-1,000,000 \mathrm{ppm} \text {, } \\
\text { depending on the type of drilling fluid }\end{array}$ & $\begin{array}{l}\text { Yan et al., } \\
2003\end{array}$ \\
\hline $\begin{array}{l}\text { SBFs }(\text { EBFs, } \\
\text { IOBFs, and } \\
\text { paraffin) }\end{array}$ & $\begin{array}{l}\text { Grandidierella sp. (Gsp) } \\
\text { (Crustacea) } \\
\text { Paphies elongata }(\mathrm{Pe}) \\
\text { (Mollusca) }\end{array}$ & Acute & $\begin{array}{c}96 \mathrm{~h} \\
10 \text { days }\end{array}$ & Adults & $\begin{array}{c}10 \mathrm{~d}, \mathrm{LC} 50=200-1,500 \mathrm{mg} \mathrm{kg}^{-1}(G s p) \\
20,000 \mathrm{mg} \mathrm{kg}^{-1}(\mathrm{Pe})\end{array}$ & \\
\hline $\begin{array}{l}\text { OBF (diesel oil) } \\
\text { and SBF (IO) }\end{array}$ & $\begin{array}{l}\text { Leptocheirus plumulosus } \\
\text { (Crustacea) }\end{array}$ & Acute & $96 \mathrm{~h}$ & $\begin{array}{l}\text { Randomly } \\
\text { selected }\end{array}$ & $\begin{array}{l}\text { Natural sediments: LC50 = 2,825 mg } \\
\mathrm{kg}^{-1}(95 \% \mathrm{CL} 568-14,042) \text {; formulated } \\
\text { sediments: } 3,795 \mathrm{mg} \mathrm{kg}^{-1}(95 \% \mathrm{CL} \\
\text { 3,284-4,385); diesel: } 539-703 \mathrm{mg} \mathrm{kg}^{-1} \text {; } \\
\text { drilling fluids: } 1,609-3,720 \mathrm{mg} \mathrm{kg}^{-1} \text {, } \\
\text { depending on the type }\end{array}$ & $\begin{array}{l}\text { Still et al., } \\
\qquad 2000\end{array}$ \\
\hline OBFs and WBFs & $\begin{array}{l}\text { Tilapia guineensis } \\
\text { (Fish) }\end{array}$ & Acute & $96 \mathrm{~h}$ & Juveniles & $\begin{array}{l}\text { WBF: } \mathrm{LC} 50=125 \mathrm{mg} \mathrm{L}^{-1} \\
\text { NABF: } 6,000 \mathrm{mg} \mathrm{L}^{-1}\end{array}$ & $\begin{array}{l}\text { Imarhiagbe } \\
\text { and Atuanya, } \\
2017\end{array}$ \\
\hline $\begin{array}{l}\text { OBFs (washed and } \\
\text { non-washed muds) }\end{array}$ & $\begin{array}{c}\text { Desmocaris trispinosa } \\
\text { (Dt) } \\
\text { Palaemonetes africanus } \\
\text { (Pa) } \\
\text { (Crustacea) }\end{array}$ & Acute & $96 \mathrm{~h}$ & Adults & $\begin{array}{c}\text { Washed cuttings: } \\
\begin{array}{c}\text { LC50 }=16,900-17,200 \mathrm{mg} \mathrm{L}^{-1}(P a) \\
9,800-10,900 \mathrm{mg} \mathrm{L}^{-1}(D t) \\
\text { unwashed cuttings: } \\
\text { LC50 }=10,300-11,350 \mathrm{mg} \mathrm{L}^{-1}(P a) \\
6,200-6,700 \mathrm{mg} \mathrm{L}^{-1}(D t)\end{array}\end{array}$ & $\begin{array}{l}\text { Okogbueet } \\
\text { al., } 2016\end{array}$ \\
\hline $\begin{array}{l}\text { WBFs (barite and } \\
\text { bentonite) }\end{array}$ & $\begin{array}{l}\text { Geodiabarretti } \\
\text { (Spongia) }\end{array}$ & $\begin{array}{l}\text { Acute and } \\
\text { Chronic }\end{array}$ & $\begin{array}{l}12 \mathrm{~h}, \\
14 \mathrm{~d}\end{array}$ & $\begin{array}{l}\text { Size range: } \\
0.1-1 \mathrm{~kg}\end{array}$ & $\begin{array}{l}\text { Reduced lysosomal membrane stability } \\
\text { using } 50 \text { and } 100 \mathrm{mg} \mathrm{L}^{-1} \mathrm{TSS} \text { barite after } \\
12 \mathrm{~h} \text {; after } 14 \text { days, it was reduced using } \\
\quad 30 \mathrm{mg} \mathrm{L}^{-1}\end{array}$ & $\begin{array}{l}\text { Edge } \text { et al., } \\
\quad 2016\end{array}$ \\
\hline WBFs and SBFs & $\begin{array}{l}\text { Argopecten nucleus } \\
\text { (Mollusca) }\end{array}$ & $\begin{array}{l}\text { Acute and } \\
\text { Chronic }\end{array}$ & $\begin{array}{l}96 \mathrm{~h}, \\
30 \mathrm{~d}\end{array}$ & Juveniles & $\begin{array}{l}96 \text { h, WBF: LC50 = 9,113-50,446 ppm; } \\
\text { SBF: } 40,520->1,000,000 \mathrm{ppm} ; \\
30 \text { d, larger toxic effect on survival and } \\
\text { growth with WBF than with SBF }\end{array}$ & $\begin{array}{l}\text { Rodríguez- } \\
\text { Satizábalet } \\
\text { al., } 2015\end{array}$ \\
\hline WBFs and OBFs & $\begin{array}{l}\text { Ammonia tepida } \\
\text { (Foraminifera) }\end{array}$ & Chronic & $30 \mathrm{~d}$ & Adults & $\begin{array}{l}\text { Reduction of pseudopodal activity with } \\
\geq 500 \mathrm{mg} \mathrm{L}^{-1} \mathrm{NABF} \text { and } \geq 100 \mathrm{mg} \mathrm{L}^{-1} \\
\text { WBF }\end{array}$ & $\begin{array}{c}\text { Denoyelleet } \\
\text { al., } 2012\end{array}$ \\
\hline SBFs & $\begin{array}{l}\text { Oreochromis } \\
\text { mossambicus } \\
\text { (Fish) }\end{array}$ & $\begin{array}{l}\text { Acute and } \\
\text { Chronic }\end{array}$ & $96 \mathrm{~h}$ & Adults & $\begin{array}{l}\text { SP: } \mathrm{LC} 50=37,550 \mathrm{mg} \mathrm{L}^{-1} \\
\text { SPP: } 40,390 \mathrm{~m} \mathrm{~L}^{-1}\end{array}$ & $\begin{array}{l}\text { Jagwaniet } \\
\text { al., } 2011\end{array}$ \\
\hline
\end{tabular}


Table 2. Data from the reviewed articles showing the effects after short- and long-term exposure to different drilling muds.

\begin{tabular}{|c|c|c|c|c|c|c|}
\hline Drilling fluid & Species & Test type & $\begin{array}{l}\text { Time of } \\
\text { exposure }\end{array}$ & Animal stage & Response & $\begin{array}{c}\text { Authors, } \\
\text { year }\end{array}$ \\
\hline WBF (barite) & $\begin{array}{l}\text { Cerastoderma edule } \\
\text { Macoma balthica } \\
\text { (Mollusca) }\end{array}$ & $\begin{array}{l}\text { Acute and } \\
\text { Chronic }\end{array}$ & $12 \mathrm{~d}$ & Adults & $\begin{array}{l}100 \% \text { dead at the end of the experiment; } \\
\text { gill damage: ctenidia severely affected }\end{array}$ & $\begin{array}{l}\text { Barlow and } \\
\text { Kingston, } \\
2001\end{array}$ \\
\hline SBF (Parateq) & $\begin{array}{l}\text { Tilapia guineensis } \\
\quad \text { (Fish) }\end{array}$ & $\begin{array}{l}\text { Acute and } \\
\text { Chronic }\end{array}$ & $\begin{array}{c}96 \mathrm{~h}, \\
12 \text { weeks }\end{array}$ & $\begin{array}{l}\text { Adults } \\
\text { and post- } \\
\text { fingerlings }\end{array}$ & $\begin{array}{l}\text { Long-term inhibition of oocyte } \\
\text { maturation and delay in spermatogenesis; } \\
\qquad 96 \mathrm{~h}, \mathrm{LC} 50=5,47 \%\end{array}$ & $\begin{array}{l}\text { Vincent- } \\
\text { Akpu and } \\
\text { Chindah, } \\
2009\end{array}$ \\
\hline
\end{tabular}

AC: additive component; EROD: ethoxyresorufin-O-deethylase; HSP: heat shock protein; EC50 : effective concentration; $\mathrm{LC}_{50}$ : median lethal concentration; LOEC : lowest effect concentration; NABFs: non-aqueous-based fluid; OBF: oil-based fluid; SBF: synthetic-based fluid; SDH: sorbitol dehydrogenase; SP: solid phase; SPP: suspended particulate phase; TSS: total suspended solid concentration; WBF: water-based fluid.

vary greatly, showing $\mathrm{LC}_{50}(96 \mathrm{~h})$ values as low as $101 \mathrm{mg}$ $\mathrm{kg}^{-1}$ of $\mathrm{Glycol}^{\mathrm{TM}}$ (Ogeleka and Tudararo-Aherobo, 2011) to $3,720 \mathrm{mg} \mathrm{kg}^{-1}$ of IOBF in Crustacea (Still et al., 2000) and $20,000 \mathrm{mg} \mathrm{kg}^{-1}$ of EBF, IOBF, and paraffin in Mollusca (Tsvetnenkoet al., 2000); this also demonstrates a higher sensitivity in crustaceans than in mollusks (Table 4).

\section{Chronic effects}

The long-term effects of WBF in invertebrates have been described as a reduction in lysosomal membrane stability in sponges, which may begin after as little as $1 \mathrm{~h}$ of exposure at concentrations of $50-100 \mathrm{mg} \mathrm{L}^{-1}$ or after 14 days at a concentration of $30 \mathrm{mg} \mathrm{L}^{-1}$ (Edge et al., 2016; Table 4). Also,

Table 3. Short- and long-term effects on vertebrates of different kind of drilling fluids, obtained from the literature review and organized by ontogenetic stage and type of drilling fluid or component.

\begin{tabular}{lccc}
\hline Taxonomic level & WBFs & Natural OBFs & SBFs \\
\cline { 3 - 4 } & & LC50 $(96 \mathrm{~h})=$ & LC50 $(96 \mathrm{~h})=$ \\
Juveniles & LC50 $(96 \mathrm{~h})=$ & $6,000 \mathrm{mg} \mathrm{L}^{-1}(1)$ & No information available \\
(Fish $)$ & $125 \mathrm{mg} \mathrm{L}^{-1}(1)$ & Long-term & Long-term, $>20$ days:
\end{tabular}

No information available

No information available

Adults

(Fish)

$$
\text { LC50 }(96 \mathrm{~h})=
$$

No information available

$$
\text { LC50 }(96 \mathrm{~h})=
$$

SP:

$$
31,107 \mathrm{mg} \mathrm{L}^{-1} \text { (mar) }
$$$$
200,000 \mathrm{mg} \mathrm{L}^{-1} \text { (fsw) (3) }
$$

SPP:

42,614 $\mathrm{mg} \mathrm{L}^{-1}$ (mar)

243,652 $\mathrm{mg} \mathrm{L}^{-1}$ (ben),

$770,000 \mathrm{mg} \mathrm{L}^{-1}$ (fsw) (3)

$\mathrm{OBF}$ :

$16,713 \mathrm{mg} \mathrm{L}^{-1}$ (mar)

$22,414 \mathrm{mg} \mathrm{L}^{-1}$ (fsw),

$167,340 \mathrm{mg} \mathrm{L}^{-1}$ (ben) (3)

Long-term

No information available
Long-term

No information available
Increase of EROD, HSP-70, and SDH activity; increase of pyrene metabolite and

DNA damage (2)

LC50 $(96 \mathrm{~h})=$

2,210 $\mathrm{mg} \mathrm{L}^{-1}$ (Parateq) (4),

$37,550 \mathrm{mg} \mathrm{L}^{-1}(\mathrm{SP})$, and

40,390 $\mathrm{mg} \mathrm{L}^{-1}$ (SPP)

from the Indian well (5);

$5.5 \%$ (Parateq) (6),

$7.8 \%$ (XP-07) (7)
Long-term, 3 months:

decrease in oocyte maturation;

delayed spermatogenesis (6)

$\mathrm{LC}_{50}$ : median lethal concentration; EROD: ethoxyresorufin-O-deethylase; SDH: sorbitol dehydrogenase; HSP: heat shock protein; SP: solid phase; SPP: suspended particulate phase; mar: marine; fsw: freshwater; ben: benthonic; (1) Imarhiagbe and Atuanya, 2017; (2) Bakhtyar and Gagnon, 2012; Gagnon and Bakhtyar, 2013; (3) Sil et al., 2012; (4) Vincent-Akpu and Sikoki, 2013; (5) Jagwaniet al., 2011; (6) Vincent-Akpu and Chindah, 2009; (7) Vincent-Akpuet al., 2010. 
Table 4. Short- and long-term effects on invertebrates of different kind of drilling fluids obtained from the literature review and organized by ontogenetic stage and type of drilling fluid.

\begin{tabular}{|c|c|c|c|}
\hline \multirow[t]{2}{*}{ Taxonomic level } & \multirow[t]{2}{*}{ WBFs } & \multicolumn{2}{|r|}{ NABFs } \\
\hline & & Natural OBFs & SBFs \\
\hline \multirow{3}{*}{$\begin{array}{l}\text { Gametes } \\
\text { (Echinodermata) }\end{array}$} & $1 \mathrm{~h}:$ & & \\
\hline & Fecundity inhibition & No information available & No information available \\
\hline & $3,649 \pm 400 \mathrm{mg} \mathrm{L}^{-1}(1)$ & & \\
\hline Post-larvae & $\operatorname{LC} 50(96 \mathrm{~h})=$ & & $\operatorname{LC} 50(96 \mathrm{~h})=$ \\
\hline (Crustacea) & $4,224-26,635$ ppm (2) & No information available & $40,781-308,248$ ppm (2) \\
\hline Juveniles & & & $\operatorname{LC} 50(96 \mathrm{~h})=$ \\
\hline (Crustacea) & No information available & No information available & SPP: $12,000-1,000,000 \mathrm{ppm}(3)$ \\
\hline \multirow[t]{2}{*}{ (Mollusca) } & $\operatorname{LC} 50(96 \mathrm{~h})=$ & $\operatorname{LC50}(96 \mathrm{~h})=$ & $\operatorname{LC50}(96 \mathrm{~h})=$ \\
\hline & $9,113-50,446 \mathrm{ppm}(4)$ & No information available & $40,500->1,000,000 \mathrm{ppm}(4)$ \\
\hline \multirow[t]{2}{*}{ (Mollusca) } & Long-term, 30 days: & Long-term: & Long-term, 30 days: \\
\hline & $\begin{array}{l}\text { Toxic effect on survival and } \\
\text { growth }\end{array}$ & No information available & Toxic effect on survival and growth \\
\hline \multicolumn{4}{|l|}{ Adults } \\
\hline \multirow[t]{5}{*}{ (Crustacea) } & $\operatorname{LC} 50(96 \mathrm{~h})=$ & $\operatorname{LC} 50(96 \mathrm{~h})=$ & $\operatorname{LC} 50(96 \mathrm{~h})=$ \\
\hline & $320 \mathrm{mg} \mathrm{L}^{-1}(5)$ & $2,825 \mathrm{mg} \mathrm{kg}^{-1}(6)$ & $101 \mathrm{mg} \mathrm{kg}^{-1}\left(\mathrm{Glycol}^{\mathrm{TM}}\right)(8)$ \\
\hline & & $6,200-17,200 \mathrm{mg} \mathrm{L}^{-1}(7)$ & $210-620 \mathrm{mg} \mathrm{kg}^{-1}$ (lubricants) (9) \\
\hline & & & $200-1,500 \mathrm{mg} \mathrm{kg}^{-1}(\mathrm{E}, \mathrm{IO}$, paraffin $)(10)$ \\
\hline & & & $1,600-3,720 \mathrm{mg} \mathrm{kg}^{-1}$ (IOBF) (6) \\
\hline \multirow[t]{2}{*}{ (Mollusca) } & & & $\operatorname{LC} 50(96 \mathrm{~h})=$ \\
\hline & No information available & No information available & $20,000 \mathrm{mg} \mathrm{kg}^{-1}$ (EBF, IOBF, and paraffin) (10) \\
\hline \multirow[t]{4}{*}{ (Spongia) } & $12 \mathrm{~h}:$ & & \\
\hline & $\begin{array}{c}\text { Decrease in lysosomal membrane } \\
\text { stability }\end{array}$ & No information available & No information available \\
\hline & $50-100 \mathrm{mg} \mathrm{L}^{-1}(11)$ & & \\
\hline & Long-term: & Long-term: & Long-term: \\
\hline \multirow[t]{4}{*}{ (Nematoda) } & 10 days: & & \\
\hline & $\begin{array}{l}\mathrm{LC}_{50}(10 \mathrm{~d})=8.82 \mathrm{ppm} \mathrm{Ba} \\
\text { decrease of population size: }\end{array}$ & No information available & No information available \\
\hline & $400-2,000 \mathrm{ppm} \mathrm{Ba}$ and & & \\
\hline & $2.40-2.68 \mathrm{ppm} \mathrm{Cd}(12)$ & & \\
\hline \multirow[t]{2}{*}{ (Mollusca) } & $4-19$ days & & \\
\hline & $\begin{array}{c}\text { Std. particulate barite and ilmenite: } \\
100 \% \text { dead, gill ctenidia severely } \\
\text { damaged (13) }\end{array}$ & No information available & No information available \\
\hline \multirow[t]{3}{*}{ (Spongia) } & 14 days: & & \\
\hline & Decrease of lysosomal membrane & No information available & No information available \\
\hline & $\begin{array}{c}\text { stability at } \\
30 \mathrm{mg} \mathrm{L}^{-1}(11)\end{array}$ & & \\
\hline \multirow[t]{2}{*}{ (Foraminifera) } & 30 days: & 30 days: & \\
\hline & $\begin{array}{l}\text { Decreased pseudopodal activity at } \\
\quad \geq 100 \mathrm{mg} \mathrm{L}^{-1}(14)\end{array}$ & $\begin{array}{l}\text { Decreased pseudopodal activity at } \\
\qquad \geq 100 \mathrm{mg} \mathrm{L}^{-1}(14)\end{array}$ & No information available \\
\hline
\end{tabular}

$\mathrm{LC}_{50}$ : median lethal concentration; SPP: suspended particulate phase; mar: marine; fsw: freshwater; ben: bentonic; EBF: ester-based fluid; (IOBF) isomerized olefin-based fluid. (1) Benavides et al., 2014.; (2) Contreras-León et al., 2013; (3) Yan et al., 2003; (4) Rodríguez-Santizábalet al., 2015; (5) Farkas et al., 2017; (6) Still et al., 2000; (7) Okogbueet al., 2016; (8) Ogeleka and Tudararo-Aherobo et al., 2011; (9) Otaigbeet al., 2006; (10) Tsvetnenkoet al., 2000; (11) Edge et al., 2016; (12) Lira et al., 2011; (13) Strachan and Kingston, 2012; (14) Denoyelleet al., 2012. 
a decrease in Nematoda population size was observed with concentrations as low as $2.4 \mathrm{ppm} \mathrm{Cd}$ and $400 \mathrm{ppm} \mathrm{Ba} \mathrm{(Lira}$ et al., 2011). In mollusks, standard-sized barite $(20.1 \mu \mathrm{m})$ and ilmenite $(12.8 \mu \mathrm{m}) \mathrm{WBFs}$ caused the death of all mollusks tested between the 4th and 19th days of exposure, due to physical interference with gill function (Strachan and Kingston, 2012). Finally, WBF caused a decrease in foraminifera pseudopodal activity after 30 days at concentrations $\geq 100 \mathrm{mg} \mathrm{L}^{-1}$, with effects only seen for OBF when the concentration was $\geq 500$ $\mathrm{mg} \mathrm{L}^{-1}$ (Denoyelleet al., 2012); this again demonstrates the higher toxicity of WBF over NABFs.

\section{Final remarks}

Environmental studies evaluating the impact of petroleum exploration on coastal organisms have shown to be relevant and continuous over the years. Such studies have been most abundant in developing countries and those in which the offshore oil industry has recently been growing; this is because such countries need to provide subsidies to industrial managers for getting environmental licenses. In general, acute tests were the most common, which can be explained by their low cost, the small-scale infrastructure needed, and their rapid results. Invertebrates were the most commonly used aquatic organisms in testing the toxicity of drilling fluids. Through our review, we can highlight some gaps in the knowledge about the toxicity of drilling fluids, such as the absence of studies of the acute and chronic effects of WBF in both juvenile and adult fish; studies of the chronic effects of NABFs in adult invertebrates; studies including micro- or mesocosm experiments; and studies with benthic organisms that produce information about the marine floor.

WBF were shown to be more toxic than NABFs, although they can suffer biodegradation mediated by fungi and bacteria (Imarhiagbe \& Atuahya, 2017). SBFs were recommended initially as containing low-toxicity components for the marine biota, based on results of acute tests (Holdway, 2002). Nonetheless, more recently, chronic assays have demonstrated that SBFs may have chronic effects on aquatic organisms at long-term exposure (Gagnon and Bakhtyar, 2013), which may be related to their low biodegradability. New synthetic component shave been developed to improve the performance of OBFs, giving them a biodegradability similar to that of WBFs (Sil et al., 2012) to minimize their impact on the environment. Nonetheless, there are large variations in the toxicity of these components, making toxicological tests necessary in order to choose components with low toxicity for petroleum exploration (Bakhtyar and Gagnon, 2012; Otaigbeet al., 2016).

Despite the limitations of toxicity tests, including their failure to faithfully reproduce exposure to the levels experienced in the natural environment, such tests can provide valuable information about the potential effects of drilling fluids on aquatic organisms. In addition, the open possibilities for studying the toxicity of other offshore waste, such as that generated from cementing operations. Toxicity evaluations may promote the use of environmentally friendly products and ACs, replacing those that have proven to be harmful to marine biota.

\section{CONCLUSIONS}

\section{Toxicity of drilling fluids and sensitivity of organisms}

WBFs were, in general, more toxic to juvenile and adult invertebrates than were SBFs after short-term exposure. WBFs showed higher toxicity to juvenile fish $\left(\mathrm{LC}_{50}[96 \mathrm{~h}]=125 \mathrm{mg}\right.$ $\left.\mathrm{L}^{1}\right)$ than did OBFs. OBFs showed less toxicity to juvenile fish $\left(\mathrm{LC}_{50}[96 \mathrm{~h}]=6,000 \mathrm{mg} \mathrm{L}^{-1}\right)$, and even less to adult marine fish $\left(\mathrm{LC}_{50}[96 \mathrm{~h}]=16,713 \mathrm{mg} \mathrm{L}^{-1}\right)$; however, marine fish were the most sensitive to drilling fluids when compared to freshwater and benthonic fish.

$\operatorname{Glycol}^{\mathrm{TM}}\left(101 \mathrm{mg} \mathrm{kg}^{-1}\right)$ and Parateq $\left(2,210 \mathrm{mg} \mathrm{L}^{-1}\right)$ in adult invertebrates and vertebrates, respectively, were the most toxic SBF. In mollusks, standard-sized barite $(20.1 \mu \mathrm{m})$ and ilmenite $(12.8 \mu \mathrm{m}) \mathrm{WBFs}$ were the most toxic because of their long-term physical interference with gill function. Juvenile mollusks (min. $\mathrm{LC}_{50}[96 \mathrm{~h}]=40,500 \mathrm{ppm}$ ) and adult mollusks $\left(20,000 \mathrm{mg} \mathrm{kg}^{-1}\right)$ were less sensitive to SBFs than were juvenile crustaceans (min, $\mathrm{LC}_{50}[96 \mathrm{~h}]=12,000 \mathrm{ppm}$ ) and adult crustaceans $\left(3,720 \mathrm{mg} \mathrm{kg}^{-1}\right)$.

\section{Information gaps}

There was no information available during the period analyzed about the toxic effects of SBFs on juvenile fish, nor of the toxic effects of WBFs on adult fish. The chronic effects on vertebrates (fish, in this case) have only been evaluated in relation to SBFs, with an absence of studies on the toxic effects of WBFs and OBFs on juvenile and adult fish. The long-term effects of OBFs and SBFs on invertebrates have also been neglected, as these effects were only studied in relation to foraminifera.

We can conclude that future studies need to address the acute and chronic effects of WBFs on both juvenile and adult fish and on other vertebrates; in addition, the chronic effects of NABFs on adult invertebrates must be investigated. As crustaceans were more sensitive to drilling fluids than were mollusks, it is recommended that they be used in future studies.

\section{REFERENCES}

BAKHTYAR, S. \& GAGNON, M.M. 2012. Toxicity assessment of individual ingredients of synthetic-based drilling muds (SBMs). Environ. Monit. Assess., 184 (9): 5311-5325. http://dx.doi.org/ 10.1007/s10661-011-2342-x.

BARLOW M.J. \& KINGSTON, P.F. 2001. Observations on the effects of barite on the gill tissues of the suspension feeder Cerastodermaedule (Linné) and the deposit feeder Macomabalthica (Linné). Mar. Pollut. Bull., 42(1): 71-76. http:// dx.doi.org/10.1016/S0025-326X(00)00117-X

BENAVIDES, S.M., BENAVIDES, S.M.C., SANTOS-ACEVEDO, M., CERÓN, A.E.G., OSPINA-SALAZAR, G.H., FIGUEROA, M.A. I. \& GÓMEZ-LEÓN, J. 2014. Acute toxicity assessment of an offshore exploration fluid for the fertilization sea Urchin Lytechinus 
Variegatus. Bol. Investig. Mar. Costeras, 43(2): 383-405.

BRITISH PETROLEUM (BP). 2018. BP Statistical Review of World Energy. 67th Edition. https://www.bp.com/content/dam/ $\mathrm{bp} / \mathrm{en} /$ corporate/pdf/energy-economics/statistical-review/bpstats-review-2018-oil.pdf. Accessed 6th November 2018.

CONTRERAS-LEÓN, G.J., RODRIGUEZ-SATIZÁBAL, S.A., CASTELLANOS-ROMERO, C.M., FRANCO-HERRERA, A. \& SERRANO-GÓMEZ, M. 2013. Acute toxicity of drilling muds on Litopenaeusvannamei (Boone, 1931) postlarvae. Cienc. Tecnol. Futuro, 5(3): 127-138. http://dx.doi. org/10.29047/01225383.52

DENOYELlE, M., GESLIN, E., JORISSEN, F.J. \& CAZES, L. 2012. Innovative use of foraminifera in ecotoxicology: a marine chronic bioassay for testing potential toxicity of drilling muds. Ecol Indic, 12(1): 17-25. https://doi.org/10.1016/j. ecolind.2011.05.011

EDGE, K.J., JOHNSTON, E.L., DAFFORN, K.A., SIMPSON, S.L., KUTTI, T. \& BANNISTER, R.J. 2016. Sub-lethal effects of water-based drilling muds on the deep-water sponge Geodiabarretti. Environ. Pollut., 212: 525-534. https://doi.org/ 10.1016/j.envpol.2016.02.047

FARKAS, J., BÅDSVIK, C.Y., ALTIN, D., NORDTUG, T., OLSEN, A.J. \& HANSEN, B.H. 2017. Acute and physical effects of waterbased drilling mud in the marine copepod Calanus finmarchicus. J Toxicol Env Heal A, 80(16-18): 907-915. https://doi.org/10.1 080/15287394.2017.1352197

GAGNON, M.M. \& BAKHTYAR, S. 2013. Induction of fish biomarkers by synthetic-based drilling muds. PLoS ONE, 8(7): e69489. https://doi.org/10.1371/journal.pone.0069489

GALVÃO T.F. \& PEREIRA, M.G. 2014. Revisões sistemáticas da literatura: passos para sua elaboração. Epidemiol. Serv. Saúde, 23(1): 183-184. http://dx.doi.org/10.5123/S167949742014000100018

GANDHI, S.M. \& SARKAR, B.C. 2016. Essentials of Mineral Exploration and Evaluation. Chapter 8: Drilling. Elsevier, New York, p. 199-234.

GOMES, I.S. \& CAMINHA, I.O. 2014. Guia para estudos de revisão sistemática: uma opção metodológica para as ciências do movimento humano. Movimento, 20(1): 395.

HOLDWAY, D.A. 2002. The acute and chronic effects of wastes associated with offshore oil and gas production on temperate and tropical marine ecological processes. Mar. Pollut. Bull., 44(3): 185-203. https://doi.org/10.1016/S0025-326X(01)00197-7

IMARHIAGBE, E.E. \& ATUANYA, E.I. 2017. Assessment of biodegradation and toxicity of drill-muds used in an onshore active field located in Edo State, Nigeria. Jordan J. Biol. Sci., 10(2): 63 .

JAGWANI, D., SHUKLA, P., KULKARNI, A., RAMTEKE, D.S. \& JUNEJA, H.D. 2011. Organ specific distribution of PAHs in a carnivorous fish species following chronic exposure to used synthetic-based drilling mud. PolycyclAromatCompd, 31(4): 227-242. https://doi.org/10.1080/10406638.2011.585371

LIRA V.F., SANTOS, G.A.P., DERYCKE, S., LARRAZABAL, M.E.L., FONSÊCA-GENEVOIS, V.G. \& MOENS, T. 2011. Effects of barium and cadmium on the population development of the marine nematode Rhabditis (Pellioditis) marina. Mar. Environ. Res., 72(4): 151-159. https://doi.org/10.1016/j. marenvres.2011.07.003

MAGALHÃES, D.P. \& FERRÃO-FILHO, A.S.A. 2008. Ecotoxicologia como ferramenta no biomonitoramento de ecossistemas aquáticos. Oecol. Aust., 12(3): 355-381.

OGELEKA, D.F. \& TUDARARO-AHEROBO L.E. 2011. Shortterm toxicity of oil-based drilling fluid to the brackish-water shrimp Palaemonetes africanus. Afr. J. Mar. Sci., 36(1): 109112. https://doi.org/10.2989/16085914.2011.559707

OKOGBUE, C.O., ANYIAM, O.A. \& ADUN, A.A. 2016. Impact assessment of drilling waste generated in "Eden Field" offshore, Niger Delta, Nigeria. Arab J Geosci, 538: 1-9. https://doi. org/10.1007/s12517-016-2568-6

OTAIGBE, J.O.E., OSUJI, L.C. \& AZUBIKE, A.N. 2006. Quantal response of Paleomonetes africanus in locally formulated drilling mud lubricants. Toxicol. Environ. Chem., 88(4): 719727. https://doi.org/10.1080/02772240600903029

RAND, G.M., WELLS, P. \& MCCARTY, L.S. Introduction to aquatic toxicology. In: Rand, G.M. (Ed) Fundamentals of Aquatic Toxicology: Effects, Environmental Fate and Risk Assessment. Washington: Taylor \& Francis, 1995.

RODRÍGUEZ-SATIZÁBAL, S.A., CASTELLANOS, C., CONTRERAS, G., FRANCO, A. \& SERRANA, M. 2015. Efectos letales y subletales en juveniles de Argopectennucleusexpuestos a lodos de perforación. Bol. Investig. Mar. Costeras, 44(2): 303-326.

SANZONE, D.M.; VINHAEIRO, N. \& NEFF, J.M. 2018. Environmental fates and effects of ocean discharge of drill cuttings and associated drilling fluids from offshore oil and gas operations. Technical Report. Available at: $<$ https://www. researchgate.net/publication/299285673_Environmental_Fates and Effects of Ocean Discharge of Drill Cuttings and Associated_Drilling_Fluids_From_Offshore_Oil_and_Gas_ Operations $>$. Accessed on: January 2018.

SIL, A. et al. 2012. Toxicity characteristics of drilling mud and its effect on aquatic fish populations. J. Hazard. Toxic Radioact. Waste, 16(1): 51-57.

STILL, I.; RABKE, S.; CANDLER, J. 2000. Development of a standardized reference sediment to improve the usefulness of marine benthic toxicity testing as a regulatory tool. Environ. Toxicol., 15(5): 406-416. https://doi.org/10.1002/15227278(2000)15:5<406::AID-TOX8>3.0.CO;2-\%23

STRACHAN, M.F. \& KINGSTON, P.F.A. 2012. Comparative study on the effects of barite, ilmenite and bentonite on four suspension feeding bivalves. Mar. Pollut. Bull., 64 (10): 2029-2038. https:// doi.org/10.1016/j.marpolbul.2012.06.023

TERZAGHI, C., BUFFAGNI, M., CANTELLI, D., BONFANTI, P. \& CAMATINI, M. 1998. Physical-chemical and ecotoxicological evaluation of water based drilling fluids used in Italian off-shore. Chemosphere, 37(14-15): 2859-2871. https://doi.org/10.1016/ S0045-6535(98)00328-2

TSVETNENKO Y.B., BLACK, A.J. \& EVANS, L.H. 2000. Development of marine sediment reworker tests with western Australian species for toxicity assessment of drilling mud. Environ. Toxicol., 15(5): 540-548. https://doi.org/10.1002/15227278(2000)15:5<540::AID-TOX26>3.0.CO;2-A

VINCENT-AKPU, I.F., ALLISON, M.E. \& SIKOKI F.D. 2010. Survival and gill morphology of different life stages of "Tilapia guineensis" exposed to the drilling fluid XP-07. Ciênc. Rural, 40(3): 611-616.

VINCENT-AKPU, I.F. \& CHINDAH, A.C. 2009. Gonad histology in post fingerling of Tilapia guineensis exposed to Parateq. Rev. Cient. UDO Agríc., 9(3): 672-680.

VINCENT-AKPU, I.F. \& SIKOKI F.D. 2013. Toxicity of drilling Fluid Parateq on Microbial Load and Survival of Oreochromis niloticus Fingerlings. J Fish Aquat Sci, 8: 218-222. https://doi. org/10.3923/jfas.2013.218.222

YAN, T., ZHOU, M., TAN, Z., LI, Z., LI, J., YU, R. \& WANG, L. 2003. Application of Neomysisawatschensis as a standard marine toxicity test organism in China. J EnvironSci , 15(6): 791-795.

ZAGATTO, P.A.; BERTOLETTI, E. 2008. Ecotoxicologia aquática: princípios e aplicações. RiMa, São Carlos.

ZHU, H.; LIU, X. 2015. Application of microtox biological toxicity testing technique in drilling fluid analysis. Drill. Fluid Complet. Fluid, 32(1): 53-56. 